\title{
Assessment of anthropogenic, seasonal and aquatic vegetation effects on the contamination level of oxbows
}

\author{
J. T. Kundrát ${ }^{1}$, Zs. Balogh ${ }^{1}, \mathrm{~S}$. Harangi ${ }^{1}$, B. Tóthmérész ${ }^{1,3}$ and E. Simon ${ }^{2}$ \\ 'Department of Ecology, University of Debrecen, Debrecen, Egyetem sq. 1, H-4032 Hungary \\ ${ }^{2} M T A-D E$ Biodiversity and Ecosystem Services Research Group, Debrecen, Egyetem sq. 1, H-4032 Hungary \\ ${ }^{3}$ Corresponding author. E-mail: tothmerb@gmail.com
}

Keywords: Heavy metals, Monitoring, Surface water, Water chemistry.

\begin{abstract}
The contamination level of oxbows depends on both natural and anthropogenic effects. The aim of our study was to identify those abiotic and biotic factors that determine the contamination level of oxbows. The effect of anthropogenic activities, seasonality, and vegetation types was studied on the contamination level of surface water of oxbows. The following chemical variables were measured: suspended solid, ammonium, nitrate, chlorophyll-a, $\mathrm{Al}, \mathrm{Ba}, \mathrm{Fe}, \mathrm{Mn}, \mathrm{Pb}, \mathrm{Sr}$ and $\mathrm{Zn}$ from eight oxbows from 2013 summer to 2014 autumn in the Upper Tisza region in Eastern Hungary. Three of the studied oxbows were protected, four oxbows were used for fishing and one oxbow was contaminated with wastewater. Our findings revealed that anthropogenic activities had remarkable effect on the contamination level of oxbows. Seasonality also influenced the contamination level, except the concentration of suspended solid, chlorophyll-a and manganese. Significant differences were found among vegetation types for the concentration of suspended solids, aluminium, iron, manganese and lead. The high level of iron concentration was not explained by the anthropogenic activities, suggesting that the quality of oxbows depends on both natural and anthropogenic effects.
\end{abstract}

Abbreviations: EPA - European Protection Agency; MP-AES -Microwave Plasma-Atomic Emission Spectrometer.

Nomenclature: The Plant List (2013).

\section{Introduction}

Water pollution is a global problem and clean water is a crucial resource for drinking, industry, fishing and agricultural activities (Schwarzenbach et al. 2010). Increasing water pollution causes not only higher contamination level of water but also contributes to the loss of habitats and reduces biodiversity (Lepom et al. 2009, Viaroli et al. 2016). Tisza river and the oxbows in the Tisza region are partly exposed to pollution (Balogh et al. 2017, Simon et al. 2017). In the Tisza region, the main anthropogenic activities are traditional land use, farming intensification, irrigation and pesticide treatment (Balogh et al. 2016, Varga et al. 2013). The main landscape form include intensively cultivated croplands, oxbows and meadows in the floodplain of Tisza river (Snedzimir et al. 2010, Werners et al. 2009). Oxbows are connected to the Tisza river during floods only, when large amounts of suspended particles and associated metals are transported by the river (Nguyen et al. 2009, Szabó et al. 2005). Thus, the flooding events may determine a cascade of effects on the contamination level of water and sediment (Walters and Babbar-Sebens 2016, Watson et al. 2016).

The contamination level of oxbows within a region is governed by both natural and anthropogenic effects (Pejman et al. 2009). Among the natural effects, seasonality must also be considered in the assessment of contamination level
(Garizi et al. 2011, Ouyang et al. 2006, Varol and Sen 2009). Pollutants can enter the aquatic ecosystem by many transport pathways, which are seasonal-dependent (Ouyang et al. 2006). Thus, seasonality has important impacts on the contamination level of oxbows (Delpha et al. 2009, Shrestha and Kazama 2007).

Aquatic macrophytes have also important influences on the physical and chemical variables of water (Lukács et al. 2009, 2011). Aquatic plants are used for the assessment of contamination level of oxbows; they can remove trace metals by selective absorption and surface adsorption and incorporate them into their system or store them in a bound form (Boz and Gumiero 2016, Hernández-Crespo et al. 2016, Pappalardo et al. 2016). In the case of emergent and floating leaved plants, the main route of pollutant uptake was through the roots, while in the roots of submerged plants as well as their leaves take part in removing pollutants and nutrients (Dhote and Dixit 2009). At the same time, emergent macrophytes have more supportive tissues than floating leaved plants. Thus, emergent plants have greater potential for the storage of nutrients and pollutants than floating leaved plants (Juwarker et al. 1995). The aim of this study was to determine how the abiotic and biotic factors influence the contamination level of oxbows. The results of our study may provide useful information for the nature management and conservation of oxbows. 
Table 1. Characteristics of the studied oxbows.

\begin{tabular}{|c|c|c|c|c|}
\hline Name & Utilization & GPS coordinates & $\begin{array}{l}\text { Depth of the oxbows } \\
(\mathrm{cm}, \text { mean } \pm \mathrm{SD})\end{array}$ & $\begin{array}{c}\text { Area of } \\
\text { oxbows }\left(\mathrm{m}^{2}\right)\end{array}$ \\
\hline Boroszló-kert & protected & $48^{\circ} 05^{\prime} 10^{\prime \prime} \mathrm{N}, 22^{\circ} 24^{\prime} 41^{\prime \prime} \mathrm{E}$ & $191 \pm 113$ & 88056 \\
\hline Foltos-kert & protected & $48^{\circ} 06^{\prime} 01^{\prime \prime} \mathrm{N}, 22^{\circ} 23^{\prime} 02^{\prime \prime} \mathrm{E}$ & $119 \pm 73$ & 24702 \\
\hline Tiszadob & protected & $48^{\circ} 00^{\prime} 47^{\prime \prime} \mathrm{N}, 21^{\circ} 11^{\prime} 15^{\prime \prime} \mathrm{E}$ & $107 \pm 99$ & 342386 \\
\hline Gyüre & fishing & $48^{\circ} 11^{\prime} 03^{\prime \prime} \mathrm{N}, 22^{\circ} 15^{\prime} 58^{\prime \prime} \mathrm{E}$ & $197 \pm 257$ & 74042 \\
\hline Vargaszeg & fishing & $48^{\circ} 06^{\prime} 15^{\prime \prime} \mathrm{N}, 22^{\circ} 33^{\prime} 57^{\prime \prime} \mathrm{E}$ & $131 \pm 111$ & 34895 \\
\hline Tuzsér & fishing & $48^{\circ} 19^{\prime} 24^{\prime \prime} \mathrm{N}, 22^{\circ} 05^{\prime} 58^{\prime \prime} \mathrm{E}$ & $103 \pm 54$ & 19701 \\
\hline Szabolcs & fishing & $48^{\circ} 10^{\prime} 20^{\prime \prime} \mathrm{N}, 21^{\circ} 30^{\prime} 18^{\prime \prime} \mathrm{E}$ & $57 \pm 36$ & 37182 \\
\hline Tímár & sewage contaminated & $48^{\circ} 08^{\prime} 36^{\prime \prime} \mathrm{N}, 21^{\circ} 27^{\prime} 03^{\prime \prime} \mathrm{E}$ & $129 \pm 62$ & 14154 \\
\hline
\end{tabular}

\section{Materials and methods}

\section{Study area and sample collection}

The studied eight oxbows are located in the floodplain area of the Tisza river near the Hungarian-Ukrainian border. Three of them are protected (Boroszló-kert oxbow, Foltoskert oxbow and Tiszadob oxbow). Four lakes (Gyüre oxbow, Vargaszeg oxbow, Tuzsér oxbow and Szabolcs oxbow) are used for fishing (Table 1). One of them (Tímár oxbow) is regularly contaminated with domestic sewage in a diffuse way (Balogh et al. 2016, 2017).

Surface water samples were collected from these oxbows during 2 years and three seasons (ISO 5667-4:1987). Surface water samples were taken from seven locations from Foltoskert, Vargaszeg, Gyüre, Tímár, Tuzsér and Szabolcs. Eleven samples were collected from Boroszló-kert and fifteen water samples were collected from Tiszadob from various vegetation plots. Three aquatic plant groups were used to study the effect of vegetation on chemical variables of water in the studied oxbows. The first group included floating leaved aquatic plants with Trapa natans, Nymphaea alba, Nuphar lutea and Polygonum amphibium as the most frequent species. The second group consisted of submerged aquatic plants of which Myriophillum verticillatum, Potamogeton lucens, Ceratophyllum demersum and Utricularia vulgaris were typical. The third group was of the emergent aquatic plants characterized by Phragmites australis, Typha angustifolia and Typha latifolia. The control group was open water without vegetation (Balogh et al. 2016).

\section{Analysis of chemical variables of water}

The $\mathrm{pH}$ was measured with WTW $\mathrm{pH} 315 \mathrm{i}$ portable field instrumentation, conductivity and temperature were measured with WTW Cond. 340i portable field instrument. For the laboratory process, the samples were stored at $4{ }^{\circ} \mathrm{C}$. In laboratory studies, from the original sample suspended solid, chlorophyll-a and ammonia-ion concentration were analysed as described by Németh (1998). We used filtered samples of nitrite, nitrate, ortho-phosphate concentration determination which is filtered through filter paper $0.45 \mu \mathrm{m}$ pore size. For trace element analysis, samples were filtered with $0.45 \mu \mathrm{m}$ pore size filter paper, and then conserved in concentrated nitric acid $\left(50 \mathrm{ml}\right.$ sample of $0.5 \mathrm{ml}$ conc. $\mathrm{HNO}_{3}$ ). The trace element concentrations were measured with Microwave Plasma-Atomic Emission Spectrometer (MP-AES) (Agilent MP-AES 4100). Certified reference material was included in each batch of samples during the measurement. The analytical error was less than $10 \%$ of the certified values for metals. For the assessment of quality the MSZ 12749 (1993) standard classification was used.

\section{Statistical analysis}

The IBM SPSS Statistics 20.0 package was used for statistical analysis. The chemical variables of surface water in the oxbows, seasons and vegetation types were analysed by canonical discriminant analysis (CDA) (Shrestha and Kazama 2007). Homogeneity of variance was tested by Levene test (Gastwirth et al. 2009). The differences among oxbows, seasons and vegetation on chemical variables of surface water were tested by three-way ANOVA (Leščešen et al. 2015). The factors were the oxbows, the seasons and the vegetation types. In the case of significant differences, Tukey's Multiple Comparison test was used. At the same time, when the variances were heterogeneous, the Kruskal-Wallis non parametric test was used (Landau and Everitt 2004).

\section{Results}

Effects of anthropogenic activities on the contamination level of oxbows

Based on the studied variables, the protected, fishing and wastewater polluted oxbows were separated from each other by canonical discriminant analysis (Fig. 1). The canonical discriminant functions were significant $(P<0.001)$. There was an overlap in each case. The first discriminant function showed positive correlation with the concentration of strontium $(r=0.414)$, zinc $(r=0.256)$, lead $(r=0.206)$, barium $(r=0.200)$. Significant positive correlation was found be- 

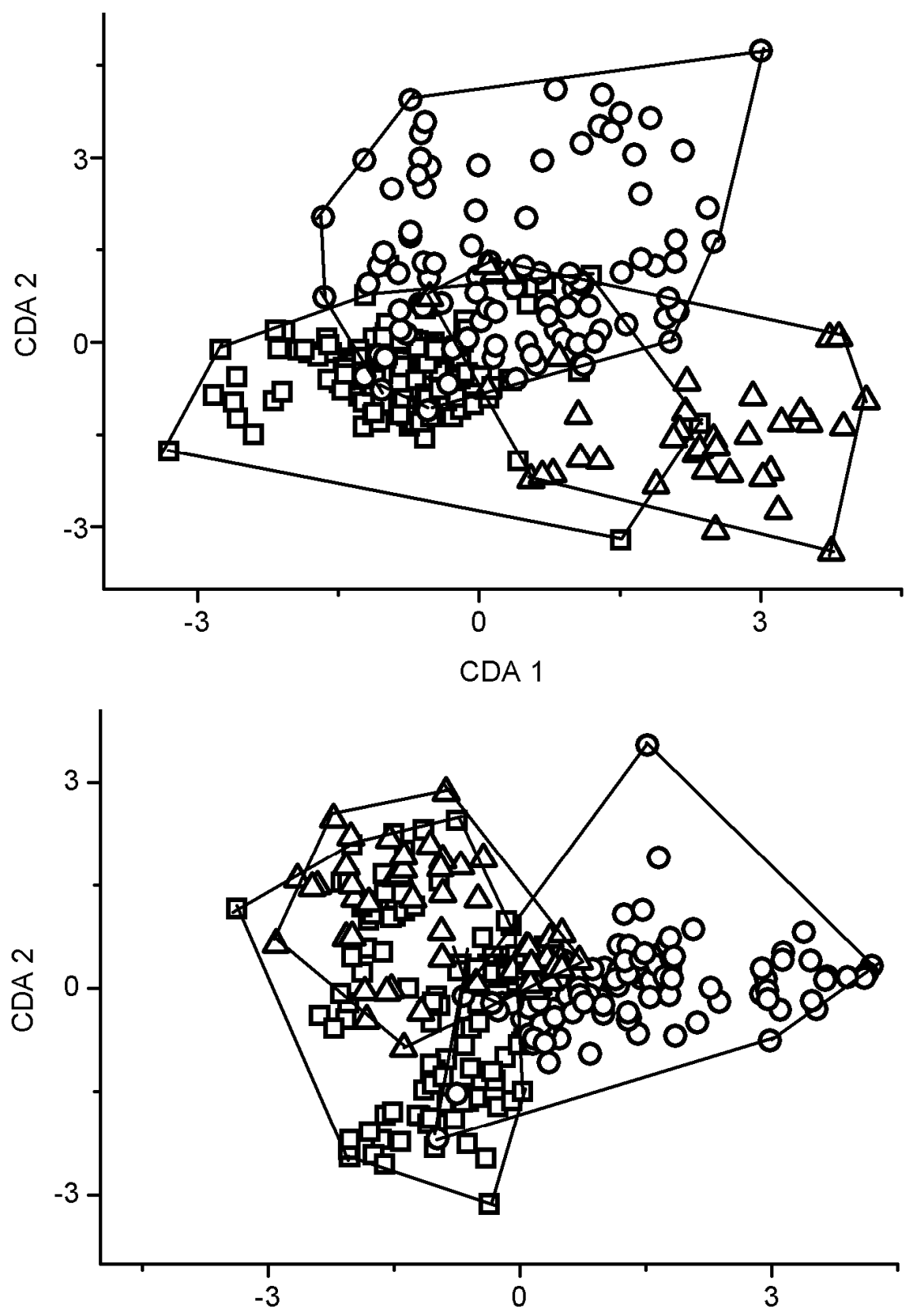

Figure 1. Separation of water samples according to anthropogenic activities based on the studied variables $\left(\mathrm{mgL}^{-1}\right)$ by canonical discriminant analysis. Notations: $\boldsymbol{\square}$ - protected oxbows, $\mathbf{O}$ - fishing oxbows, $\boldsymbol{\Delta}$-wastewater polluted oxbow.

Figure 2. Seasonal separation of water samples based on the studied variables (mgL-1) by canonical discriminant analysis. Notations: $\boldsymbol{\square}$ - summer, O- autumn, $\Delta$ - spring.

CDA 1

tween the second discriminant function and the concentration of aluminium $(r=0.692)$, suspended solid $(r=0.588)$, iron ( $r=0.369)$, chlorophyll-a $(r=0.320)$, ammonium $(r=0.175)$ and manganese $(r=0.159)$. At the same time, significant negative correlation was found between the second discriminant function and the concentration of nitrate $(r=-0.102)$.

Using ANOVA, all variables were significantly different among the protected, fishing and wastewater polluted oxbows, except for temperature, $\mathrm{pH}$ and concentration of nitrate $(P>0.05)$. Higher conductivity results were found in the wastewater polluted oxbow than in the protected and fishing lakes $(P<0.01)$. In the cases of suspended solid and iron, significantly higher concentration was found in the protected oxbows, than in the fishing and wastewater pol- luted lakes $(P<0.05)$. At the same time, the concentration of these variables was significantly higher in the fishing oxbow, than in the wastewater polluted ones. There were no significant differences in the concentration of ammonium and chlorophyll-a between protected and wastewater polluted oxbows, but in the fishing oxbows the concentration of these variables was significantly lower than in the other oxbows $(P<0.05)$. The lead and strontium concentration was significantly higher in the protected and fishing oxbows than in the wastewater polluted oxbows. The aluminium concentration was the highest in the fishing oxbows, while the barium concentration was the highest in the fishing and protected oxbows. However, significant difference was found between fishing and wastewater polluted oxbow $(P<0.05)$. 
The highest Mn concentration was found in the protected oxbows, which differed significantly from wastewater polluted oxbows. Significantly higher $\mathrm{Zn}$ concentration was found in the fishing and wastewater polluted than in the protected oxbows $(P<0.05)$ (Table 2$)$.

\section{Effects of seasonality on the contamination level of oxbows}

Similarly to the anthropogenic activities, separation was found among seasons based on the variables of water (Fig. $2)$. The canonical discriminant functions were also significant $(P<0.001)$. High overlap was found among the seasons based on the studied variables in water. Significant negative correlation was found between the first discriminant function and the concentration of lead $(r=-0.276)$, aluminium $(r=-0.238)$ and chlorophyll-a $(r=-0.048)$. For ammonium, there was a positive correlation with the first discriminant function $(r=0.674)$. The second discriminant function correlated positively with the concentration of barium $(r=0.624)$, nitrate $(r=0.384)$, strontium $(r=0.377)$, zinc $(r=0.316)$ and manganese $(r=0.101)$. Negative correlation was found between second discriminant function and the concentration of suspended solid materials $(r=-0.193)$ and iron $(r=-0.181)$.

Significant differences were found among seasons based on the studied variables of water, except the $\mathrm{pH}$, the conductivity and the concentration of suspended solid, chlorophyll-a and manganese $(P>0.05)$. The concentration of ammonium was significantly higher in autumn than in summer and spring. In spite of this, the nitrate concentration was similar in autumn and spring, which was significantly higher than in summer $(P<0.05)$. At the same time, the temperature and the concentration of aluminium, lead and zinc was the highest in summer and spring $(P<0.05)$. Among the other variables, the concentration of iron and strontium was significantly lower in autumn than in summer, whereas no significant difference was found for iron between summer and spring (Table 2).

\section{Effects of vegetation types on the contamination level of oxbows}

In spite of anthropogenic activities and seasonality, we found no separation among the vegetation types based on the variables of water. Significant difference was found only in the first discriminant function $(P<0.05)$. The concentration of suspended solid ( $r=0.458)$, aluminium $(r=0.457)$, strontium $(r=0.381)$ and lead $(r=0.318)$ correlated positively with the first discriminant function.

Using the Kruskal-Wallis test, significant differences were found among vegetation types in the case of the concentration of suspended solids, aluminium, iron, manganese and lead $(P<0.05)$. Significantly higher suspended solid and iron concentration was found in the water samples collected from the emergent vegetation, than in the floating leaves vegetation and open water. In the case of aluminium highest concentration was found near the emergent vegetation, which was significantly different from the other vegetation types. The manganese concentration was higher in the submerged vegetation than the floating leaves. In case of lead, significantly higher concentration was found in the emergent vegetation than in the open water (Table 2).

\section{Discussion}

Our results suggest that the contamination level of oxbows depends on both abiotic and biotic factors. The results indicated that ammonium, nitrate, aluminium, barium, iron, manganese, lead, strontium and zinc were stongly fluctuating during the seasons. In spite of earlier findings (Vitt et al. 1995), our results demonstrated that ammonium was not independent of seasons, because its concentration was higher in the warmer seasons than in autumn. Similarly to the findings of Vitt et al. (1995), our results show that the aluminium, iron, zinc and nitrate concentration fluctuated seasonally. The concentration of these variables was higher in the warmer seasons than in autumn.

Many studies demonstrated that aquatic macrophytes could be related unambiguously to water chemistry (Rai et al. 1995, Samecka-Cymerman and Kempers 2001). At the same time, only a few studies demonstrated that the ionic concentrations in water could be related to macrophyte species (Lee and McNaughton 2004; Maine et al. 1999). Our study illustrated that the vegetation types influence the following variables: suspended solid, aluminium, iron, manganese and lead. The highest suspended solid concentration was found in the emergent vegetation type, which may exclude rooted macrophytes from reaches (Wood and Armitage 1997). However, Zambrano et al. (2001) reported that the suspended solid was showed to closely related fish biomass. At the same time, emergent macrophytes have more supportive tissues than floating leaves, so they have greater potential for storing nutrients and pollutants (Juwarker et al. 1995). In spite of our results, Maine et al. (1999) found no differences in the concentration of elements in the water of emergent and submerged plants as compared to open sites.

In summary, based on the EPA standards (EPA 1986) our results were higher than the threshold in the case of aluminium $\left(>0.75 \mathrm{mg} \mathrm{L}^{-1}\right)$ and zinc $\left(>0.1 \mu \mathrm{g} \mathrm{L}^{-1}\right)$ which indicated the high contamination level of oxbows based on the concentration of these elements. Our results revealed that the anthropogenic activities and seasonality had remarkable effect on the contamination level of oxbows, except for the concentration of suspended solid, chlorophyll-a and manganese in the case of seasonality. Significant differences were found among vegetation types in the case of the concentration of suspended solids, aluminium, iron, manganese and lead. Similarly to earlier studies our results also demonstrated that if the studied oxbows are relatively undisturbed from wind; the individual chemical differences can associate with macrophyte species (Lee and McNaughton 2004, Maine et al. 1999). Thus, the contamination level of oxbows depends on abiotic and biotic factors, respectively. Since the high level of iron concentration was not explained by the anthropogenic activities, our results indicated that similarly to other studies (Ouyang et al. 2006, Pejman et al. 2009) the contamination level of oxbows depends on both natural and anthropogenic effects. 


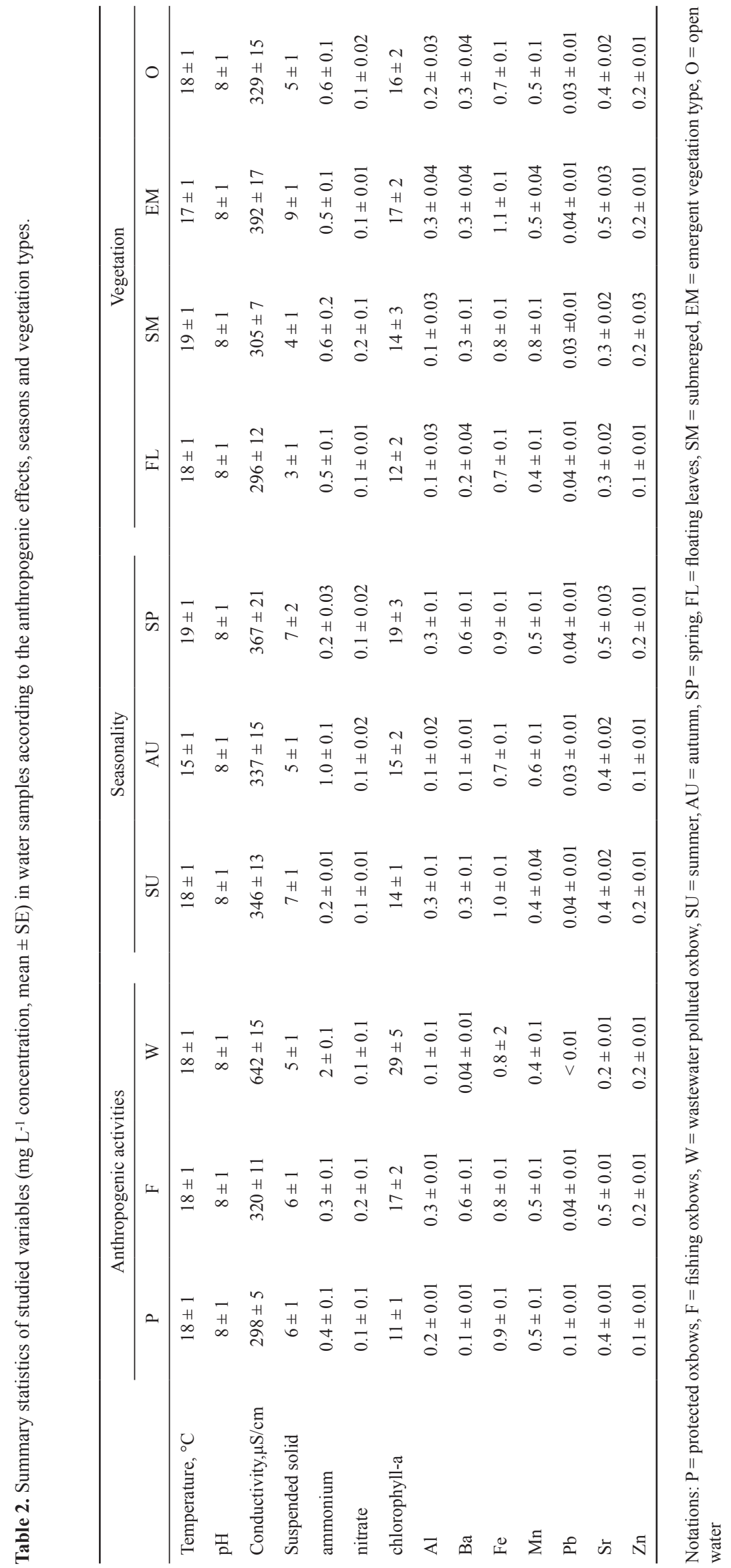


Acknowledgements: The research was supported by the Internal Research Project of the University of Debrecen (E. Simon). The study was supported by the SROP-4.2.2.B-15/1/ KONV20150001 project.

\section{References}

Balogh, Zs., Harangi, S., Kundrát, J.T., Gyulai, I., Tóthmérész, B. and Simon, E. 2016. Effects of anthropogenic activities on the elemental concentration in surface sediment of oxbows. Water Air Soil Pollut. 227:13-21.

Balogh, Zs., Harangi, S., Gyulai, I., Braun, M., Hubay, K., Tóthmérész, B. and Simon, E. 2017. Exploring river pollution based on sediment analysis in the Upper Tisza region (Hungary). Environ. Sci. Pollut. R. 24:4851-4859.

Boz, B. and Gumiero, B. 2016. Nitrogen removal in an afforested riparian zone: the contribution of denitrification processes. Hydrobiologia 774:167-182.

Delpha, I., Jung, A.V., Baures, E., Clement, M. and Thomas, O. 2009. Impacts of climate change on surface water quality in relation to drinking water production. Environ. Int. 35:1225-1233.

Dhote, S. and Dixit, S. 2009. Water quality improvement through macrophytes - a review. Environ. Monit. Assess. 152:149-153.

EPA, 1986. Quality Criteria for Water, "Gold Book". https://www. epa.gov/wqc/national-recommended-water-quality-criteriaaquatic-life-criteria-table.

Garizi, A.Z., Sheikh, V. and Sadoddin, A. 2011. Assessment of seasonal variations of chemical characteristics in surface water using multivariate statistical methods. Int. J. Environ. Sci. Tech. 8:581-592.

Gastwirth, J.L., Gel, Y.R. and Miao, W. 2009.The Impact of Levene's test of equality of variances on statistical theory and practice. Stat. Sci. 24:343-360.

Hernández-Crespo, C., Oliver, N., Bixquert, J., Gargallo, S. and Martínez, M. 2016. Comparison of three plants in a surface flow constructed wetland treating eutrophic water in a Mediterranean climate. Hydrobiologia 774:183-192.

ISO 5667-4:1987. Water quality. Sampling. Part 4: Guidance on sampling from lakes, natural and man-made. International Organization for Standardization, Vernier, Geneva, Switzerland.

Juwarker, A.S., Oke, B., Juwarkar, A. and Patnaik, S.M. 1995. Domestic wastewater treatment through constructed wetland in India. Water Sci. Technol. 32:291-294.

Landau, S. and Everitt, B.S. 2004. A Handbook of Statistical Analyses Using SPSS. Chapman \& Hall/CRC Press, Boca Raton.

Lee, P.F. and McNaughton, K.A. 2004. Macrophyte induced microchemical changes in the water column of a northern Boreal Lake. Hydrobiologia 522:207-220.

Lepom, P., Brown, B., Hanke, G., Loos, R., Quevauviller, P. and Wollgast, J. 2009. Needs for reliable analytical methods for monitoring chemical pollutants in surface water under the European Water Framework Directive. J. Chromatogr. A 1216:302-315.

Leščešen, I., Pantelić, M., Dolinaj, D., Stojanović, V. and Milošević, D. 2015. Statistical analysis of water quality parameters of the Drina River (West Serbia), 2004-11. Pol. J. Environ. Stud. 24:555-561.

Lukács, B.A., Dévai, Gy. and Tóthmérész, B. 2009. Aquatic macrophytes as bioindicators of water chemistry in nutrient rich backwaters along the Upper-Tisza river (in Hungary). Phytocoenologia 39:287-293.
Lukács, B.A., Dévai, Gy. and Tóthmérész, B. 2011. Small scale macrophyte-environment relationship in an oxbow-lake of the Upper-Tisza valley (Hungary). Community Ecol. 12:259-263.

Maine, M.A., Noemi, L.S., Panigatti, M.C., Pizarro, M.J. and Emilani, F. 1999. Relationships between water chemistry and macrophyte chemistry in lotic and lentic environments. Arch. Hydrobiol. 145:129-145.

Németh, J. 1998. A biológiai vízminősítés módszerei. Methods for water quality management (in Hungarian). Környezetgazdálkodási Intézet TOI Környezetvédelmi Tájékoztató Szolgálat, Budapest.

Nguyen, H.L., Braun, M., Szalóki, I., Baeyens, W., Van Grieken, R. and Leemarkers, M. 2009. Tracing the metal pollution history of the Tisza River through the analysis of a sediment depth profile. Water Air Soil Poll. 200:119-132.

Ouyang, Y., Nkedi-Kizza, P., Wu, Q.T., Shinde, D. and Huang, C.H. 2006. Assessment of seasonal variations in surface water quality. Water Res. 40:3800-3810.

Pappalardo, S.E., Otto, S., Gasparini, V., Zanin, G. and Borin, M. 2016. Mitigation of herbicide runoff as an ecosystem service from a constructed surface flow wetland. Hydrobiologia 774:193-202.

Pejman, A.H., Bidhendi, G.R.N., Karbassi, A.R., Mehrdadi, N. and Bidhendi, M.E. 2009. Evaluation of spatial and seasonal variations in surface water quality using multivariate statistical techniques. Int. J. Environ. Sci. Tech. 6: 467-476.

Rai, U.N., Sinka, S., Tripathi, R.D. and Chandra, P. 1995. Wastewater treatability potential of some aquatic macrophytes: removal of heavy metals. Ecol. Eng. 5:5-12.

Samecka-Cymerman, A. and Kempers, A.J. 2001. Concentrations of heavy metals and plant nutrients in water, sediments and aquatic macrophytes of anthropogenic lakes (former open cut brown coal mines) differing in stage of acidification. Sci. Total Environ. 281:87-98

Schwarzenbach, R.P., Egli, T., Hofstetter, T.B., von Gunten, U. and Wehrli, B. 2010. Global water pollution and human health. Annu. Rev. Environ. Resour. 35:109-136.

Sendzimir, J., Flachner, Zs., Pahl-Wostl, C. and Knieper, C. 2010. Stalled regime transition in the upper Tisza River Basin: the dynamics of linked action situations. Environ. Sci. Policy 13:604619.

Shrestha, S. and Kazama, F. 2007. Assessment of surface water quality using multivariate statistical techniques: A case study of the Fuji river basin, Japan. Environ. Model. Softw. 22:464-475.

Simon, E., Kis, O., Jakab, T., Kolozsvári, I., Málnás, K., Harangi, S., Baranyai, E., Miskolczi, M., Tóthmérész, B. and Dévai, Gy. 2017. Assessment of contamination based on trace element concentration of dragonfly larvae in the Upper Tisza Region. Ecotox. Environ. Safe. 136:55-61.

Szabó, K., Kiss, K.T., Taba, Gy. and Ács, É. 2005. Epiphytic diatoms of the Tisza River, Kisköre Reservoir and some oxbows of the Tisza River after the cyanide and heavy metal pollution in 2000. Acta Bot. Croat. 64:1-46.

The Plant List (2013). Version 1.1. Published on the Internet; http:// www.theplantlist.org/ (accessed December 20, 2017).

Varga, K., Dévai, Gy. and Tóthmérész, B. 2013. Land use history of a floodplain area during the last 200 years in the Upper-Tisza region (Hungary). Reg. Environ. Change 13:1109-1118.

Varol, M. and Sen, B. 2009. Assessment of surface water quality using multivariate statistical techniques: a case study of Behrimaz Stream, Turkey. Environ. Monit. Assess. 159:543-553. 
Viaroli, P., Bartoli, M. and Vymazal, J. 2016. Preface: Wetlands biodiversity and processes - tools for conservation and management. Hydrobiologia 774:1-5.

Vitt, D.H., Bayley, S.E. and Jin, T.L. 1995. Seasonal variation in water chemistry over a bog-rich fen gradient in continental western Canada. Can. J. Fish. Aquat. Sci. 52:587-606.

Walters, K.M. and Babbar-Sebens, M. 2016. Using climate change scenarios to evaluate future effectiveness of potential wetlands in mitigating high flows in a Midwestern U.S. watershed. Ecol. Eng. 89:80-102.

Watson, E. B., Szura, K., Wigand, C., Raposa, K. B., Blount, K. and Cencer, M. 2016. Sea level rise, drought and the decline of Spartina patens in New England marshes. Biol. Conserv. 196:173-181.
Werners, S. E., Flachner, Zs., Matczak, P., Falaleeva, M. and Leemanse, R. 2009. Exploring earth system governance: A case study of floodplain management along the Tisza river in Hungary. Global Environ. Change 19:503-511.

Wood, P.J. and Armitage, P.D. 1997. Biological effects of fine sediment in the lotic environment. Environ. Manage. 21:203-217.

Zambrano, L., Scheffer, M. and Martínez-Ramos, M. 2001. Catastrophic response of lakes to benthivorous fish introduction. Oikos 94:344-350.

Received October 15, 2017

Revised November 21, 2017 Accepted December 27, 2017 